\title{
Potentials of SARs-CoV-2 transmission through bioaerosol and implications of air conditioning systems
}

\author{
Michael Chukwudi Ezeani ${ }^{*}$ and Ujuamala Uloma Ezeani ${ }^{2}$ \\ ${ }^{1}$ Department of Immunology, Faculty of Medicine, Nnamdi Azikiwe University, Nigeria \\ ${ }^{2}$ Department of pharmacology and toxicology, Faculty of pharmaceutical sciences, Nnamdi Azikiwe University, Nigeria
}

\begin{abstract}
We can avoid food and water even when we need them, but we cannot avoid air even when we don't need it. The epidemiological importance of air borne transmission should not be whisked away. While there is no evidence about aerologic transmission of SARs-CoV-2, report has indicated that SARs-CoV-2 can be air borne but only through aerosols created by medical procedures. Meanwhile, air conditioners do move air around in a room, so they theoretically pose a risk of spreading viral droplets and droplet nuclei. More research is therefore needed to understand the impact, of air conditioning on the spread of SARs-CoV-2 in public and private places. Most of the reports made today on the possibilities of transmitting SARs-CoV-2 through air condition are based on assumption. Scientific issues remain assumption or hypothesis until scientifically proven. Droplets and droplet nuclei can potentially be transmitted through air control of heat ventilation air conditioner (HVAC), considering that its mechanism could run through circulation of viral particles within the room, office, theater and laboratories, or removal of the viral particles from the room to the outside, however the scientific knowledge of the SARs-CoV-2 droplets and droplet nuclei is not yet clear. There is tendency that any air-conditioned room that the viral carrier has entered, is potential source of contacting the virus through mechanism of heat, ventilation air conditioner operation. Factors that would enable heat, ventilation air conditioner to serve as source of viral transmission are highlighted.
\end{abstract}

\section{Introduction}

The Smith Papyrus, dating back to 1600 BC, stated that the first of the incantations to the gods of sickness was devoted to cleansing the wind of the pest of the year. In the second Century A.D, Galan gave forth the ominous pronouncement, that when many sicken and die at once, we must look to a single common cause, the air we breathe $[1,2]$. This background theory, as old as it is, remains relevant in this modern time. COVID-19 is a disease caused by the SARS-CoV-2 virus, it was first reported to the WHO Country Office in China on 31 December 2019 and later became a global pandemic [3]. Hand washing, use of surgical or face mask and maintaining social distance are the main measures recommended by the World Health Organization (WHO) to avoid contracting COVID-19. Unfortunately, these measures do not prevent infection by inhalation of small droplets and droplet nuclei exhaled by an infected person that can travel distance of meters or tens of meters in the air and carry their viral content. Science explains the mechanisms of such transport and there is evidence that this is a significant route of infection in indoor environments [4].

The WHO's previous guidelines stated that only larger droplets expelled from coughs and sneezes that fall to the floor can spread the disease. This indicates that they did not acknowledge the potential for aerosol transmission. Later, WHO reported that some medical procedures can produce very small droplets (called aerosolized droplet nuclei or aerosols), that are able to stay suspended in the air for longer periods, when such medical procedures are conducted on people infected with COVID-19 in health facilities, these aerosols can contain the COVID-19 virus [3]. These aerosols may potentially be inhaled by others if they are not wearing appropriate personal protective equipment (PPE). But it has long been recognized that particles expelled during human expiratory events, such as sneezing, coughing, talking, and breathing, serve as vehicles for respiratory pathogen transmission [5,6]. Asadi et al. [7] has shown that the rate of particle emission during normal human speech is positively correlated with the loudness (amplitude) of vocalization; indicating that droplets and aerosols are on a continuum of sizes.

It could be said that compared with previous global epidemics or pandemics, humanity is much better equipped to control the new epidemic. The virus's gene sequence was identified and made public, and a testing method was developed within two weeks after its existence was announced [8], launching the race to develop a protective vaccine [9]. In addition, testing methods measuring the infection (using RTPCR) and measuring the antibodies formed after being infected (using immunoassays) $[10,11]$. Real-time statistics on all aspects of the virus's transmission are available online [12]. Countries have enacted emergency response procedures, travel bans have been put in place [13] and lockdown procedures which limit the movement of people inside the administrative zones. Despite all these, the transmission routes, a key step to the epidemic control, have not yet been fully determined. Importantly, rudimentary knowledge of several aspects of infection spread, including how SARS-CoV-2 virus is transmitted is inevitable $[14,15]$. General knowledge of viral transmission recommends spread by direct contact, touching an infected person or the surfaces and

${ }^{\star}$ Correspondence to: Michael Chukwudi Ezeani, Department of Immunology, Faculty of Medicine, Nnamdi Azikiwe University, Awka, Anambra state, Nigeria, Tel: +23-48035522824; E-mail: mc.ezeani@unizik.edu.ng

Key words: SARs-CoV-2, transmission, bio aerosol, air conditioning system, implication

Received: January 30, 2021; Accepted: March 05, 2021; Published: March 14, 2021 
fomites that the person has either touched, or on which large viruscontaining droplets released by the person have landed [16] and there, the virus can remain stable for days [17]. The droplets can also be deposited directly on a person in close proximity to the infected person. Therefore, frequent handwashing and maintaining a distance of at least one meter (arm's length) are considered the main precautions against contracting the infection [18]. These are basically important, but our defensive strategy may not be enough without comprehensive emphasis on transmission route involving aerosols which involves the droplet nuclei en route air transmission. This mode of transmission seems to be suppressed or ignored in the case of SARS-CoV-2 virus. This is why this work remains relevant in the context of COVID-19 eradication. Besides we can avoid food and water even when we need them, but we cannot avoid air even when we don't need it. The epidemiological importance of air borne transmission should not be whisked away.

It is recorded that the predecessor of SARS-CoV-2, SARS$\mathrm{CoV}-1$, did spread in the air. This was reported in several studies and retrospectively explained the pathway of transmission in Hong Kong's Prince of Wales Hospital $[19,20]$, as well as in health care facilities in Toronto, Canada [21], and in aircraft [22]. These studies concluded that airborne transmission was the main transmission route in the indoor cases studied. Other examples of airborne transmission of viral infections include the spread of Norwalk-like virus between school children [23], and the transmission of influenza A/H5N1 virus between ferrets [24]. A World Health Organization [25] review of the evidence stated that viral infectious diseases can be transmitted across distances relevant to indoor environments by aerosols (e.g., airborne infections), and can result in large clusters of infection in a short period. Basically, the most common types of viruses causing infections in the respiratory tract through aerosol transmission are influenza viruses, rhinoviruses, coronaviruses, respiratory syncytial viruses (RSVs), and parainfluenza viruses [16]. Tellier [26] has postulated three modes in which the influenza virus can be transmitted: aerosol transmission, droplet transmission, and self-inoculation of the nasal mucosa by contaminated hands. Another classification is presented by Judson and Munster [27], which is often referred to as the term of 'airborne transmission' to describe the disease spread by small droplet aerosols or droplet nuclei, while the term 'droplet transmission' describes infection by large droplet aerosols. The term 'airborne transmission' defined by Morawska [16] is quite similar to the same apprehended by Judson and Munster [27]. Considering the many similarities between the two SARS viruses and the evidence on virus transport in general, it is very likely that the SARS-CoV-2 virus also spreads by air [28]. Experts in droplet dynamics and airflow in buildings agree on this [29]. In April 1985, 175 patients were admitted to hospitals in Stafford England with chest infections or pneumonia-like symptoms. A total of 28 people died. Medical diagnosis showed that Legionnaires' disease was responsible, and the epidemiological investigation traced the source of the infection to the air-conditioning cooling tower on the roof of the Stafford District Hospital. This is in addition to the original case of the same disease in Philedelphia USA in 1977 [30]. We argue here that if history of bacteria such Legionella pneumophilia can be aerosolized and transmitted through air conditioning system, viruses like SARs-Cov-2 could as well be aerosolized and the transmission propagated through air condition.

Based on these, it is important to review the possible implication of one of the most vibrant vehicles for microbial air transmission through the Heat, ventilation air conditioning system (HVAC). COVID-19 infection in Nigeria for example experienced significant increase in wealthy individuals and office users who could have been spending higher number of hours under air conditioning system moving from office air conditioner to that of the car. This is an observation but of epidemiologic importance to implication of AC in the spread of the aerosols. Additionally, in hot Southern states in USA where people want to stay indoors and enjoy the air conditioning, ventilation is dependent on HVAC systems and there is high prevalence of COVID-19 infection in that area than in other places. Some argument has it that the infectivity in these individuals is because the virus thrives and replicates better under cold temperature than under hot temperature. However, the truth remains that between droplet and droplet nuclei (aerosol) contagion, droplet nuclei contagion is more infective or portent because one can take all the possible measures as mentioned above but cannot avoid air. "Ventilation is the key control point for an airborne virus [31]. "Based on multiple studies done by the authors, we believe that optimized ventilation is the way to move forward, removing the virus from the air before people inhale it. We think that's one of the main ways it's transmitted" [31].

Aerosol transmission of SARS-CoV-2, whether through direct respiratory droplet transfer or fomite generation, may in fact be a more important exposure transmission pathway than previously considered [32]. Fear et al. [33] through their quantitative measurement of infectivity of viral airborne efficiency complemented by qualitative assessment of virion morphology concluded that SARS-CoV-2 is viable as an airborne pathogen. Humans produce aerosols continuously through normal respiration [34]. Production of aerosols increases during respiratory illnesses [35], and even during louder-than-normal oration [36]. When we are dealing with an infectious agent that has the transmission capacity to go pandemic, we strongly believe that no stone should be left unturned because the more knowledge we have about the infectious agent, the more we prevent and eradicate the agent.

\section{Droplet, droplet nuclei and viral transmission}

In the classic study of airborne transmission, Wells [1] was able to identify the difference between disease transmission via large droplets and by airborne routes. Wells [1] found that, under normal air conditions, droplets smaller than $100 \mu \mathrm{m}$ in diameter would completely dry out before falling approximately $2 \mathrm{~m}$ to the ground. This finding allowed the establishment of the theory of droplets and droplet nuclei transmission depending on the size of the infected droplet. Aerobiology is the study of the processes involved in the movement of microorganisms in the atmosphere from one geographical location to another, including the aerosolized transmission of disease. The aerosolized transmission of disease occurs through both droplet and droplet nuclei (airborne) means [37]. Droplet transmission is defined as the transmission of diseases by expelled particles $>5-10 \mu \mathrm{m}$ that are likely to settle to a surface quickly, typically within three feet of the source [38]. Thus, for example, in order for an infection to be caused by droplet transmission, a susceptible individual must be close enough to the source of the infection (e.g., an infected individual) in order for the droplet (containing the infectious microorganism) to make contact with the susceptible individual's respiratory tract, eyes, mouth, nasal passages, and so forth. In contrast, droplet nuclei $(<5 \mu \mathrm{m})$ airborne transmission is defined as the transmission of infection by expelled particles that are comparatively smaller in size and thus can remain suspended in air for long periods of time [39]. The spread of such an infectious agent could be caused by the dissemination of droplet nuclei (aerosols) that remain infectious when suspended in air over long distances and time [39]. Transmission of SARS-CoV-2 can occur through direct, indirect, or close contact with infected people through infected secretions such as saliva and respiratory secretions or their respiratory droplets, which are expelled when an infected person coughs, sneezes, talks or sings 
[40,41]. Respiratory droplet transmission can occur when a person is in close contact (within 1 meter) with an infected person who has respiratory symptoms (e.g., coughing or sneezing) or who is talking or singing; in these circumstances, respiratory droplets that include virus can reach the mouth, nose or eyes of a susceptible person and can result in infection. Indirect contact transmission involving contact of a susceptible host with a contaminated object or surface (fomite transmission) may also be possible [42] When public health officials say that there is no sufficient evidence to say that SARS-CoV-2 is airborne, they specifically mean transported in virus-laden aerosols smaller than $5 \mu \mathrm{m}$ in diameter. Compared with droplets, which are heftier and thought to travel only short distances after someone coughs or sneezes before falling to the floor or onto other surfaces, aerosols can linger in the air for longer and travel further [29]. According to WHO [3], airborne transmission of SARS-CoV-2 can only occur during medical procedures that generate aerosols ("aerosol generating procedures"). $\mathrm{WHO}$, together with the scientific community, has been actively discussing and evaluating whether SARS-CoV-2 may also spread through aerosols in the absence of aerosol generating procedures, particularly in indoor settings with poor ventilation?. The implications here is that respiratory droplets are not airborne particles while droplet nuclei (aerosols) are airborne particles and that the major means of transmitting SARS-CoV-2 is through respiratory droplets.

Bourouiba [14] found that under the right conditions, liquid droplets from sneezes, coughs and just exhaling can travel more than 26 feet and linger in the air for minutes. The study focused on a turbulent gas, the cloud emitted when someone coughs, sneezes or exhales. Liquid droplets of various sizes drop onto surfaces, while others can be trapped in a cloud that can swirl around a room with a payload, in theory of pathogen-bearing droplets. A lot goes into how far the cloud and its droplets travel: considering a person's physiology, the environment, humidity and temperature. The cloud can reach up to 26 feet for sneezes and less than that for coughs about 16 to 19 feet [14]. According to Atkinson et al. [43] on a World Health Organization report, when someone coughs, they can spray up to 3,000 droplets. A sneeze could yield 40,000. These droplets can be very small as small and invisible as the micron size to the ones that you can see that are on the order of the millimeter". A human hair is 60 to 120 microns thick.

Airborne particles are particularly worrisome simply because they can remain suspended in the air for extended periods of time. Researchers demonstrated that airborne particles could remain airborne for as long as one week after initial aerosolization $[1,44,45]$. Thus, the droplet nuclei potentially expose a much higher number of susceptible individuals at a much greater distance from the source of infection [46]. Depending on environmental factors (e.g., meteorological conditions outdoors and fluid dynamic effects and pressure differentials indoors), airborne particles are easily measured $20 \mathrm{~m}$ from their source. These factors would be of no concern but for the fact that airborne bacterial, viral, and fungal particles are often infectious [37,47].

Looking at the current trend that the SARS-CoV-2 is often transmitted through droplets generated when a symptomatic person coughs, sneezes, talks, or exhales $[4,48]$ and that droplets are too heavy to remain in the air and rather fall on nearby floors or surfaces, it is very important, to note that some droplets, when ejected from an infected person, convert to aerosol particles (also known as bioaerosols) with relatively smaller aerodynamic diameters and, consequently, become airborne [16]. Such virus-laden aerosol particles are capable of infecting people who inhale such particles, thereby spreading the disease. Further, there have been several transport phenomena where larger droplets become smaller through evaporation so that such smaller particles are called droplet nuclei. Such aerosol particles with the encapsulation of viruses could be termed as bioaerosols or droplet nuclei [49]. Considering the impact of the most important environmental factors that could influence the viability of airborne microorganisms such as temperature, humidity, radiation (sunlight), and open-air (ventilation) [50], most viruses, including SARS-CoV-2, are less than $100 \mathrm{~nm}$ in size [51]. Viruses in aerosols loss or gain the viability and infectivity because of environmental stresses caused by temperature, relative humidity, and sunlight before they reach a susceptible host. Environmental tolerance of the virus-laden aerosols depends on the specific phenotype available, the composition of the bioaerosols containing virus and their payload, and physical characteristics in the surrounding environment [52]. As the environmental factors play a major role in transmitting payloads of SARS-CoV-2 virus in different geographical locations of outdoor and indoor environments and enabling transmission factors to ascertain the true nature of airborne transmission of SARS-CoV-2 virus (Figure 1).

The scenarios in respect of the generation of droplets and aerosol, particularly in the indoor environment, have not been adequately understood, and thus, insights into the plausible mechanisms are worthy of being explored. Duguid [53] for the first time, explored the characteristics of droplets and aerosol from human expiratory activities with chest infections. Duguid [53] observed that $95 \%$ of particles were often smaller than $100 \mu \mathrm{m}$, and the majority was between 4 and $8 \mu \mathrm{m}$. The findings corroborated that breathing and exhalation originated from the nose have shed up to a few hundreds of droplets of which
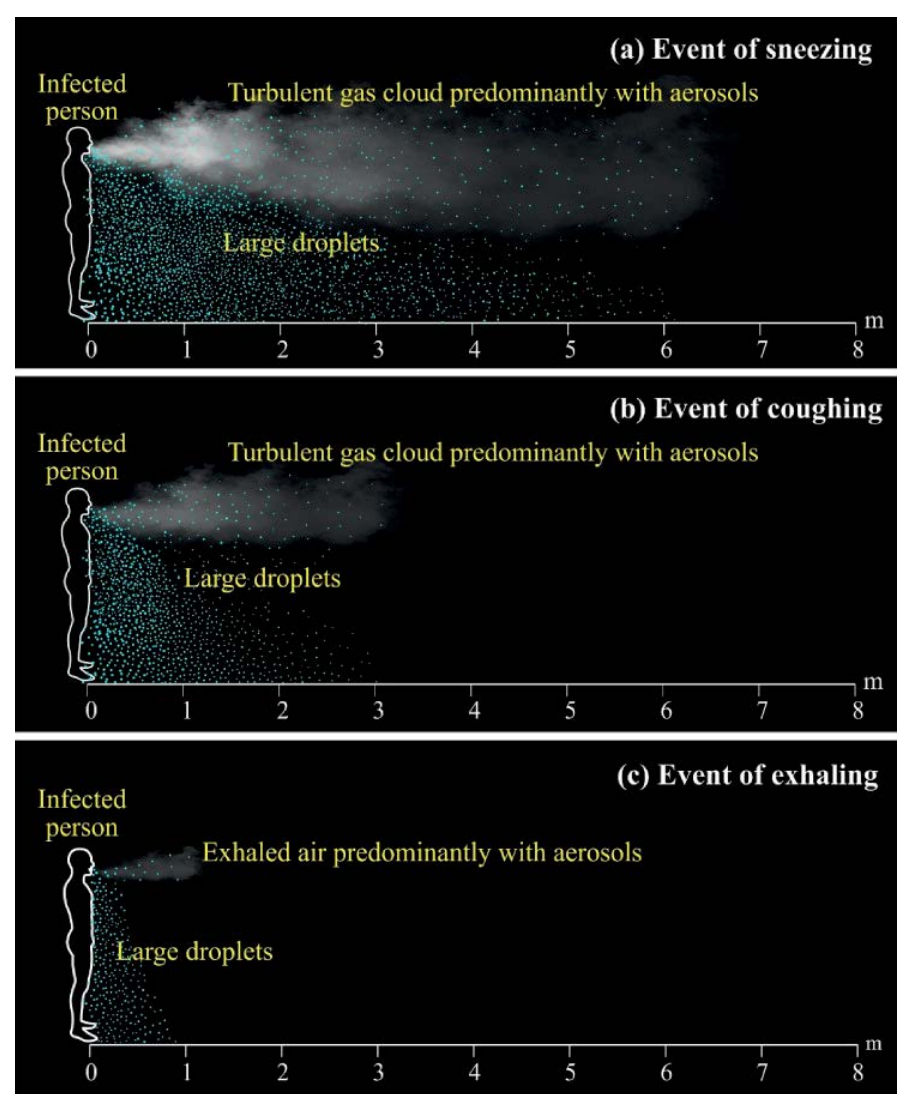

Figure 1. Trajectories of droplets and aerosols from an infected patient (a) event of sneezing with droplets travelled for $6 \mathrm{~m}$ at a speed of $50 \mathrm{~m} / \mathrm{s}$ within $0.12 \mathrm{~s}$ (b) event of coughing with droplets travelled for $2 \mathrm{~m}$ at a speed of $10 \mathrm{~m} / \mathrm{s}$ within $0.2 \mathrm{~s}$ (c) event of exhaling with droplets travelled for $1 \mathrm{~m}$ at a speed of $1 \mathrm{~m} / \mathrm{s}$ within $1 \mathrm{~s}$ [49]. 
some were aerosols. In contrast, talking, coughing, and sneezing have produced more aerosols than droplets. A complicating factor is the heterogeneous nature of droplet and droplet nuclei releases, which generally consist of mixtures of both single and multiple cells, spores, and viruses carried by both respiratory secretions and inert particles (e.g., dust) [47]. In another experiment, the comparison of short-term aerosol efficiencies of three emergent coronaviruses showed SARS$\mathrm{CoV}-2$ is on par with or exceeding the efficiency estimates of SARS-CoV and MERS-CoV [33]. Some efficiency determinations for SARS-CoV-2 ranged to $-5.5 \log ^{10}$, a full log difference compared to MERS-CoV. The fact that higher efficiencies trended across independent laboratories strengthens this observation. These data suggest that SARS-CoV-2 generally maintains infectivity when airborne over short distances, in contrast to either comparator betacoronavirus. Results of the aerosol suspension experiments suggest that SARS-CoV-2 is persistent over longer periods of time than would be expected when generated as a highly respirable particle [33]. This is remarkable as there would be an expected decay and loss in the infectious fraction of airborne virus based on prior susceptibility studies with other relatively environmentally hardy viruses like Monkeypox [54]. A recent study [17], showing only a slight reduction of infectivity in aerosol suspensions with approximately similar particle sizes, were suggestive of the minimal effects on SARS-CoV-2 infectivity observed by Fears et al. [33]. Collectively, this preliminary dataset on the aerosol efficiency and persistence of SARSCoV-2 suggest that this virus is remarkably resilient in aerosol form, even when aged for over 12 hours, and reinforces the conclusions reached in earlier studies of aerosol. The origins of droplet or airborne infectious microorganisms are also heterogeneous: infectious particles may be generated from, for example, infectious persons, heating, ventilation, and air conditioning (HVAC) systems, and cooling tower water in hospitals. All of these sources can produce airborne infectious particles [47]. Also, droplet and airborne transmission are not mutually exclusive. That is, independent of origin, particles carrying infectious microorganisms do not exclusively disperse by airborne or droplet transmission, but by both methods simultaneously [46].

Transmission of infectious disease by the airborne route is dependent on the interplay of several critical factors, primarily particle size (i.e., the diameter of the particle) and the extent of desiccation [47]. Previous works suggest that a particle's size is of central importance in determining whether it becomes and remains airborne and infectious [55-58]. Simply illustrated, large particles fall out of the air and small particles remain airborne. As indicated above, World Health Organization uses a particle diameter of $5 \mu \mathrm{m}$ to delineate between droplets nuclei (airborne) $(\leq 5 \mu \mathrm{m})$ and droplet (nonairborne) $(>5 \mu \mathrm{m})$ transmission $[59,60]$. One of the challenges facing practitioners, particularly in an enclosed building, is that even large-sized droplets can remain suspended in air for long periods [47]. The reason is that droplets settle out of air onto a surface at a velocity dictated by their mass [47]. If the upward velocity of the air in which they circulate exceeds this velocity, they remain airborne. Hence, droplet aerosols up to $100 \mu \mathrm{m}$ diameter have been shown to remain suspended in air for prolonged periods when the velocity of air moving throughout a room exceeds the terminal settling velocity of the particle [47]. Another critical variable is the rate at which particles desiccate. Immediately after droplets are expired, the liquid content starts to evaporate, and some droplets become so small that transport by air current affects them more than gravitation. Such small droplets are free to travel in the air and carry their viral content meters and tens of meters from where they originated [16]. Even large, moisture laden droplet particles desiccate rapidly. Particles begin desiccating immediately upon expulsion into the air and do so rapidly. Particles up to $50 \mu \mathrm{m}$ can desiccate completely within $0.5 \mathrm{~s}$ [1]. Rapid desiccation is a concern since the smaller and lighter the infectious particle, the longer it will remain airborne. Hence, even when infectious agents are expelled from the respiratory tract in a matrix of mucus and other secretions, causing large, heavy particles, rapid desiccation can lengthen the time they remain airborne (the dried residuals of these large aerosols, termed droplet nuclei, are typically $0.5-12 \mu \mathrm{m}$ in diameter. Of further concern, very large aerosol particles may initially fall out of the air only to become airborne again once they have desiccated [47]. The Wells evaporation-falling curve of droplets is important in understanding airborne transmission and transmission by large droplets. Wells study also demonstrated that droplets could transform into droplet nuclei by evaporation [1]. However, the consequent of desiccation should be put into consideration because not all microbial particles can survive the effect of desiccation. Fennelly [61] reported that the variability of transmission among respiratory pathogens appears to be less dependent on the physical particle size emitted by the diseased person, as current guidelines suggest, but more by biological factors such as the size of the emitted inoculum, the ability of the pathogen to survive desiccation and other stresses of aerosolization and airborne transport, and environmental factors such as air movement, temperature and humidity, and host defenses.

A recent laboratory study showed that artificially aerosolized SARS-CoV-2 survived in the air as long as SARS-CoV-1 and persisted even longer on surfaces, from where it might become resuspended by turbulent air [17]. The researchers evaluated the stability of SARSCoV-2 and SARS-CoV-1 in aerosols and on various surfaces and estimated their decay rates using a Bayesian regression model and found similarities in all the experimental conditions. SARS-CoV-2 remained viable in aerosols throughout the duration of the experiment (3 hours), with a reduction in infectious titer from $10^{3.5}$ to $10^{2.7}$ tissue culture infectious dose $\left(\mathrm{TCID}_{50}\right)$ per liter of air. This reduction was similar to that observed with SARS-CoV-1, from $10^{4.3}$ to $10^{3.5} \mathrm{TCID}_{50}$ per milliliter. The researchers also found that the stability of SARS-CoV-2 was similar to that of SARS-CoV-1 under the experimental circumstances tested. This indicates that differences in the epidemiologic characteristics of these viruses probably arise from other factors, including high viral loads in the upper respiratory tract and the potential for persons infected with SARS-CoV-2 to shed and transmit the virus while asymptomatic. Respiratory Aerosol and fomite transmission of SARS$\mathrm{CoV}-2$ is plausible, since the virus can remain viable and infectious in aerosols for hours and on surfaces up to days (depending on the inoculum shed) $[62,63]$. These findings echo those with SARS-CoV-1, in which these forms of transmission were associated with nosocomial spread and super-spreading events [64], and they provide information for pandemic mitigation efforts.

\section{Implications of HVAC}

The purpose of air conditioning, ventilation, or other climate control systems are to create "thermally comfortable" environments for people, while often also improving the quality of circulating indoor air. Studies that have examined different levels of indoor temperature and relative humidity on the transmission of SARS-CoV-1, H1N1, and MERS-CoV viruses show that lower temperature and relative humidity (below $70^{\circ} \mathrm{F} / 21^{\circ} \mathrm{C}$ and below $40 \% \mathrm{RH}$ ) increase the survival time of both coronaviruses and influenza on dry surfaces [65]. For example, SARS$\mathrm{CoV}-1$ can survive at least two weeks in an air-conditioned environment where temperature is typically $22-28^{\circ} \mathrm{C}$ and relative humidity is usually controlled at $30-60 \%$ [66]. Recent studies confirm that SARS$\mathrm{CoV}-2$ survival is comparable to SARS-CoV-1 [17]. Therefore, it is 
plausible that findings for SARS-CoV-1 are also true for SARS-CoV-2. Heating, Ventilation and Air Conditioning Systems (HVAC) are used as a primary infection disease control measure. Poor ventilation in confined indoor spaces is associated with increased transmission of respiratory infections $[67,68]$. There have been numerous COVID-19 transmission events associated with closed spaces, including some from presymptomatic cases $[69,70]$. This indicates that if not correctly used, they may contribute to the transmission/spreading of airborne diseases as proposed in the past for SARS. The role of ventilation in preventing COVID-19 transmission is not well-defined (i.e., by preventing dispersal of infectious particles to minimize the risk of transmission or preventing transfer of an infectious dose to susceptible individuals). Research has shown that airborne transmission is possible and that HVAC systems when not adequately used may contribute to the transmission of the virus, as suggested by descriptions from Japan, Germany, and the Diamond Princess Cruise Ship. Previous SARS outbreaks reported at Amoy Gardens, Emergency Rooms and Hotels, also suggested an airborne transmission [71]. Droplet nuclei floating on the air may be carried by the movement of air. Entrainment of air into neighbouring airspaces may occur during the most innocuous daily activities; for example, as a result of people walking, or the opening of a door between a room and the adjacent corridor or space [72,73]. In addition, the air temperature (and therefore air density) differences across an open doorway will also cause air exchange to occur between the two areas, providing a second mechanism to allow air into other areas $[74,75]$. If the air conditioning or ventilation system is not well maintained and operated, there are two potential mechanisms through which it could contribute to virus transmission: the system itself could recirculate contaminated air; and/or could create indoor conditions (temperature and humidity) that support virus survival. Buildings that use a central ventilation and/or climate control system, should use the most efficient filters. Consider installing a higher efficiency filter (MERV-13 to 16, EPA-2019 models), or in healthcare facilities, a HEPA filter which captures viruses effectively [76], and where the air handler is rated for such a filter. Filters should be installed and maintained according to manufacturer recommendations. High efficiency filters are also available for residential use.

Of significance here is that SARs CoV-2 can be transmitted through aerosol (airborne) and if that is the case, HVAC is suspected here to be good transport medium for transmission of SARs CoV-2 [69]. Research has shown that in COVID-19 outbreak, droplet transmission was prompted by air-conditioned ventilation. The key factor for infection was the direction of the airflow [77]. To prevent spread of COVID-19 in restaurants, Lu et al. [69] recommended strengthening temperaturemonitoring surveillance, increasing the distance between tables, and improving ventilation.

The current common denominator affecting the transmission or reduction of transmission of airborne particles in a building is its HVAC system. HVAC systems are intended to provide for the health, comfort, and safety of occupants by maintaining thermal and air quality conditions that are acceptable to the occupants $[68,78]$, through energyefficient and cost-effective methods under normal conditions [79], and, to the extent possible, they are expected to be responsive to hazardous exposures under extraordinary conditions [80]. Ventilation systems provide clean air by exchanging indoor and outdoor air and filtering. Air-conditioning systems can be part of integrated HVAC systems or stand-alone, providing cooling/warming and dehumidification. Standalone systems usually recirculate the air without mixing it with outdoor air [68]. A typical HVAC system has three basic components: (1) outdoor air intake and air exhaust ducts and controls, (2) air handling units (i.e., systems of fans, heating and cooling coils, air filters, and controls), and (3) air distribution systems (i.e., air ducts, diffusers and controls, return and exhaust air collectors, grilles, and registers, return and exhaust air ducts and plenums) [81]. HVAC systems perform multiple functions simultaneously, including controlling three known central variables in the airborne transmission of infectious particles: temperature, relative humidity, and air currents. Drawing definitive conclusions about the role that HVAC systems might play in spreading COVID-19 is difficult. There are only a few published studies looking at that issue, and experts admit there has been too little research into the role of HVAC systems in the spread of the novel coronavirus. Air conditioners have fans that blow the air around. That gives the smallest viral particles-aerosols-extra lift to remain suspended in the air for longer period. "The air currents that are produced by air conditioners and also fans and other air moving devices can carry particles further than they might otherwise go. Air conditioners also remove moisture from the air, and we know viruses prefer dry air. This virus is opportunistically airborne, you can get it by inhaling it, Air conditioning is also risky because of the way air handlers work.

Since aerosols are much smaller than droplets, aerosols can travel greater distances and get deep into the lungs of someone who inhales them. Among scientists, there has been debate about the extent to which aerosol transmission causes infection. But it has been generally accepted that it does occur, especially in closed indoor settings. Consequently, there's a possibility that air conditioning may be a potential route of transmission - sucking in virus particles breathed out by an infected person and then blowing those infectious particles back out in the same room or even another room several floors away. In fact, other infectious diseases such as measles, tuberculosis, chickenpox, influenza, smallpox and SARS have all been shown to spread through heating, ventilation and air conditioning systems. The composition and viability of indoor microbial communities and their metabolic products are determined by the characteristics of the building they inhabit, the building's occupants and their behaviors, and the surrounding external environment [82]. Biological agent would be introduced directly into the HVAC system from outside of a building via the air intake, and then distributed throughout the building [83]. Building materials, carpets, clothing, food, pets, and pests are also known sources of introduction of airborne particles into an office or commercial building [83]. Viruses that are spread easily via airborne transmission (e.g., Influenza A) can be brought into a building by infected individuals and potentially enter the return air system and be spread throughout a building by the HVAC system [83]. Such infected individuals may show no symptoms and thus hamper infection control measures (e.g., 30-50\% of humans infected with Influenza A show no symptoms [84] asymptomatic conditions also exist in SARs CoV-2. In general, however, it should be noted that the extent to which HVAC systems contribute to the airborne transmission of disease has not been quantified [83]. The air in the HVAC system passes through the air filter. The filter's job is to catch particulates and pollutants such as dust, mold, pet dander and fungal spores. The mesh that is the main namesake of the filter that air passes through becomes denser, thus catching these materials and not hindering the flow of air. If the air filter is not changed as frequently as it should, the air can't pass through as easily, as well as more and more particulars have the chance of getting through the mesh, thus harming indoor air quality.

\section{Precautionary measures}

A working group from the University of Pittsburgh Medical Center (UPMC) Biosecurity Center (Baltimore, MD, USA), including experts in air filtration, building ventilation and pressurization, air 
conditioning and air distribution, biosecurity, building design and operation, building decontamination and restoration, economics, medicine, public health, and public policy, concluded in 2005 that there are seven actionable items building owners and operators can undertake to immediately reduce the risk of building occupants to airborne particles [85]. They are (1) to minimize filter bypass by sealing, caulking, and gasket filter cartridges, retainer banks, and tracking, (2) to commission buildings during design and construction, and recommission routinely to ensure that ventilation systems are operating as intended, (3) to increase air filtration to the maximum economically justifiable MERV (Minimum Efficiency Reporting Value, a rating of air filter effectiveness) level, (4) to maintain filter systems by conducting regular inspections, (5) to ensure that HVAC maintenance staff has appropriate training to operate and maintain the HVAC system, (6) when economically feasible, tighten the building envelope to reduce the infiltration rate, and (7) when economically feasible, pressurize the building to reduce the infiltration rate. Therefore, all possible precautions against airborne transmission in indoor scenarios should be taken. Precautions include increased ventilation rate, using natural ventilation, avoiding air recirculation, avoiding staying in another person's direct air flow, and minimizing the number of people sharing the same environment [58]. Furthermore, as reported by Persily et al. [86] most commercial buildings are not configured and maintained in ways that effectively reduce occupants' risk of exposure to biological threats: The HVAC systems of most commercial buildings do not have air filtration systems sufficient to effectively remove biological contaminants from the air; this is particularly true for bacteria and viruses; Filters are frequently installed improperly and/or maintained improperly, resulting in reduced filtration efficiency as a result of filter bypass; Many commercial buildings have infiltration problems that can reduce the effectiveness of air filtration systems because air that enters a building via infiltration bypasses filtration systems; Many commercial buildings have outdoor air intakes located at or near ground level, making them more accessible; this increases occupants' vulnerability to biological attacks and also can increase vulnerability to naturally occurring threats when the air intake is near a potential contamination source [86]. Increasing ventilation indoors and not recirculating air can go some way to ensuring that infectious aerosols are diluted and flushed out, says Morawska and Cao [4]. All air conditioning and industrial ventilation systems for both residential and high occupancy buildings (government buildings, schools, hotels, and hospitals) should be inspected, maintained, and cleaned regularly to prevent transmission. Even in well-ventilated environments, people should continue following recommendations of physical distancing and frequent hand hygiene. Set temperatures between $24^{\circ} \mathrm{C} / 75^{\circ} \mathrm{F}$ and $27^{\circ} \mathrm{C} / 80.5^{\circ} \mathrm{F}$ for cooling during the warmer weather, and $\mathrm{RH}$ between $50 \%$ and $60 \%$. To reduce the number of days that the SARS-COV-2 virus can remain viable in the indoor environment, avoid setting climate control systems to low "cold" temperatures (below $21^{\circ} \mathrm{C} / 70^{\circ} \mathrm{F}$ ) [87] and "dry" low humidity settings (below $40 \%$ ) as these are optimal conditions for the virus to survive $[17,87]$.

\section{Conclusion}

It may not be possible for droplet transmission to be taking place while aerosol transmission is ruled out or limited to medical devices, due to some factors that can transform even droplets to become air borne. Other sources of aerosol other than medical devices should equally be looked into.

The assumption should be that airborne transmission is possible unless experimental evidence rules it out. That way people can take precautions to protect themselves. Moreover, as far as airborne transmission is possible, implication of Air conditioning system in transmission of SARs-Cov-2 is highly possible.

\section{References}

1. Wells WF (1934) On air-borne infection: study II. Droplets and droplet nuclei. Am J Epidemiolo 20: 611-618, 1934.

2. Ezeani MC, Agba MI, Onyenekwe CC, Anahalu I, Azikiwe CC, et al. (2011) Aerobacteriology of laboratories and offices: Evidence of high risk exposure to immune complex formation in Nigeria. Asian Paicfic J Tropical Dis 1: 131-136.

3. WHO (2020) Advice on the use of masks in the context of COVID-19. Interim guidance. Geneva: World Health Organization. Available at: https://www.who.int publications/i/item/advice-on-the-use-of-masks-in-the-community-during-home-careand-in-healthcare-settings-in-the-context-of-the-novel-coronavirus-(2019-ncov)-outbreak

4. Morawska L, Cao J (2020) Airborne transmission of SARS-CoV-2: The world should face the reality. Environ Int 139: 105730. [Crossref]

5. Tang JW (2015) Investigating the airborne transmission pathway - different approaches with the same objectives. Indoor Air 25: 119-124. [Crossref]

6. Wei J, Li Y (2016) Airborne spread of infectious agents in the indoor environment. Am $J$ Infect Control 44(9 Suppl): S102-8. [Crossref]

7. Asadi S, Wexler AS, Cappa CD, Barreda S, Bouvier NM, et al. (2019) Aerosol emission and superemission during human speech increase with voice loudness. Sci Rep 9: 2348. [Crosssref]

8. Zhu N, Zhang D, Wang W, Li X, Yang B, et al. (2020) Novel Coronavirus Investigating and Research Team. A Novel Coronavirus from Patients with Pneumonia in China, 2019. N Engl J Med 382: 727-733. [Crossref]

9. Yan R, Zhang Y, Li Y, Xia L, Guo Y, et al. (2020) Structural basis for the recognition of SARS-CoV-2 by full-length human ACE2. Science 367: 1444-1448. [Crossref]

10. Elfaitouri A, Mohamed N, Fohlman J, Aspholm R, Frisk G, et al. (2005) Quantitative PCR-enhanced immunoassay for measurement of enteroviral immunoglobulin M antibody and diagnosis of aseptic meningitis. Clin Diagn Lab Immunol 12: 235-241.

11. Souf S (2016) Recent advances in diagnostic testing for viral infections. Bioscience Horizons Int J Student Res 9: hzw010.

12. Worldometers (2020) Coronavirus statistics.

13. Tian H, Liu Y, Li Y, Wu CH, Chen B, et al. (2020) An investigation of transmission control measures during the first 50 days of the COVID-19 epidemic in China. Science 368: 638-642. [Crossref]

14. Bourouiba L (2020) Turbulent Gas Clouds and Respiratory Pathogen Emissions: Potentia Implications for Reducing Transmission of COVID-19. JAMA 323: 1837-1838. [Crossref]

15. Brosseau L (2020) Commentary: COVID-19 transmission messages should hinge on science (16 March 2020). Center for Infectious Disease Research and Policy (CIDRAP).

16. Morawska L (2006) Droplet fate in indoor environments, or can we prevent the spread of infection? Indoor Air 16: 335-347. [Crossref]

17. van Doremalen N, Bushmaker T, Morris DH, Holbrook MG, Gamble A, et al. (2020) Aerosol and Surface Stability of SARS-CoV-2 as Compared with SARS-CoV-1. N Engl J Med 382: 1564-1567. [Crossref]

18. WHO (2020) Coronavirus disease (COVID-19) advice for the public. Available at https://www.who.int/emergencies/diseases/novel-coronavirus-2019/advice-for-public.

19. Li Y, Huang X, Yu IT, Wong TW, Qian H (2005) Role of air distribution in SARS transmission during the largest nosocomial outbreak in Hong Kong. Indoor Air 15: 83-95. [Crossref]

20. Xiao S, Li Y, Wong TW, Hui DSC (2017) Role of fomites in SARS transmission during the largest hospital outbreak in Hong Kong. PLoS One 12: e0181558. [Crossref]

21. Booth TF, Kournikakis B, Bastien N, Ho J, Kobasa D, et al. (2005) Detection of airborne severe acute respiratory syndrome (SARS) coronavirus and environmental contamination in SARS outbreak units. J Infect Dis 191: 1472-1477. [Crossref]

22. Olsen SJ, Chang HL, Cheung TY, Tang AF, Fisk TL, et al. (2003) Transmission of the severe acute respiratory syndrome on aircraft. N Engl J Med 349: 2416-2422. [Crossref]

23. Marks PJ, Vipond IB, Regan FM, Wedgwood K, Fey RE, et al. (2003) A school outbreak of Norwalk-like virus: evidence for airborne transmission. Epidemiol Infect 131: 727-736. [Crossref] 
24. Herfst S, Schrauwen EJ, Linster M, Chutinimitkul S, de Wit E, et al. (2012) Airborne transmission of influenza A/H5N1 virus between ferrets. Science 336: 1534-1541. [Crossref]

25. World Health Organization (2009) Natural Ventilation for Infection Control in HealthCare Settings. Available at: https://www.who.int/water_sanitation_health/publications/ natural_ventilation.pdf

26. Tellier R (2009) Aerosol transmission of influenza A virus: a review of new studies. $J R$ Soc Interface 6 Suppl 6 (Suppl 6): S783- S790. [Crossref]

27. Judson SD, Munster VJ (2019) Nosocomial Transmission of Emerging Viruses via Aerosol-Generating Medical Procedures. Viruses 11: 940. [Crossref]

28. Fineberg, H.V., 2020. Rapid Expert Consultation on the Possibility of Bioaeroso Spread of SARS-CoV-2 for the COVID-19 Pandemic. In: The National Academies Press N.R.C., ed. Washington, DC: The National Academies Press, National Research Council 2020.

29. Lewis D (2020) Is the coronavirus airborne? Experts can't agree. Nature 580: 175. [Crossref]

30. Terranova W, Cohen ML, Fraser DW (1978) 1974 outbreak of Legionnaires' Disease diagnosed in 1977. Clinical and epidemiological features. Lancet 2: 122-124. [Crossref]

31. Padilla R, Zarracina J (2020) WHO agrees with more than 200 medical experts that COVID-19 may spread via the air USA TODAY.

32. Pung R, Chiew CJ, Young BE, Chin S, Chen MI, et al. (2020) Investigation of three clusters of COVID-19 in Singapore: implications for surveillance and response measures. Lancet 395: 1039-1046. [Crossref]

33. Fears AC, Klimstra WB, Duprex P, Hartman A, Weaver SC, et al. (2020) Comparative dynamic aerosol efficiencies of three emergent coronaviruses and the unusual persistence of SARS-CoV-2 in aerosol suspensions. medRxiv [Preprint] 18:2020.04.13.20063784. [Crossref]

34. Milton DK, Fabian MP, Cowling BJ, Grantham ML, McDevitt JJ (2013) Influenza virus aerosols in human exhaled breath: particle size, culturability, and effect of surgical masks. PLoS Pathog 9: e1003205. [Crossref]

35. Proaño A, Bravard MA, López JW, Lee GO, Bui D, et al. (2017) Dynamics of Cough Frequency in Adults Undergoing Treatment for Pulmonary Tuberculosis. Clin Infect Dis 64: 1174-1181. [Crossref]

36. Lindsley WG, Reynolds JS, Szalajda JV, Noti JD, Beezhold DH (2013) A Cough Aerosol Simulator for the Study of Disease Transmission by Human Cough-Generated Aerosols. Aerosol Sci Technol 47: 937-944. [Crossref]

37. Fernstrom A, Goldblatt M (2013) Aerobiology and its role in the transmission of infectious diseases. J Pathog 2013: 493960. [Crossref]

38. Garner JS (1996) Guideline for isolation precautions in hospitals. The Hospita Infection Control Practices Advisory Committee. Infect Control Hosp Epidemiol 17: 53-80. Erratum in: Infect Control Hosp Epidemiol 17: 214. [Crossref]

39. WHO (2014) Infection prevention and control of epidemic- and pandemic-prone acute respiratory infections in health care. Geneva: World Health Organization. Available at: https://apps.who.int/iris/bitstream/handle/10665/112656/9789241507134_eng. pdf? sequence $=$

40. Liu J, Liao X, Qian S, Yuan J, Wang F, et al. (2020) Community Transmission of Severe Acute Respiratory Syndrome Coronavirus 2, Shenzhen, China, 2020. Emerg Infect Dis 26: 1320-1323. [Crossref]

41. Luo L, Liu D, Liao X, Wu X, Jing Q, Zheng J, et al. Modes of contact and risk of transmission in COVID-19 among close contacts (pre-print). MedRxiv. 2020 doi:10.1 $101 / 2020.03 .24 .20042606$.

42. WHO (2020) Transmission of SARS-CoV-2: implications for infection prevention precautions. Scientific Brief 9 July 2020a.

43. Atkinson J, Chartier Y, Pessoa-Silva CL, et al., editors (2009) Natural Ventilation for Infection Control in Health-Care Settings. Geneva: World Health Organization; 2009. Annex C, Respiratory droplets. Available at: https://www.ncbi.nlm.nih.gov/books/ NBK143281/

44. Duguid JP (1946) The size and the duration of air-carriage of respiratory droplets and droplet-nuclei. J Hyg (Lond) 44: 471-479. [Crossref]

45. Seto WH (2015) Airborne transmission and precautions: facts and myths. J Hosp Infect 89: 225-228. [Crossref]

46. Gralton J, Tovey E, McLaws ML, Rawlinson WD (2011) The role of particle size in aerosolised pathogen transmission: a review. J Infect 62: 1-13. [Crossref]
47. Cole EC, Cook CE (1998) Characterization of infectious aerosols in health care facilities: an aid to effective engineering controls and preventive strategies. Am J Infect Control 26: 453-464. [Crossref]

48. WHO (2020) WHO announces COVID-19 outbreak a pandemic. Available at: http:/ www.euro.who.int/en/health-topics/health-emergencies/coronavirus-covid-19/news/ news/2020/3/who-announces-covid-19-outbreak-a-pandemic

49. Jayaweera M, Perera H, Gunawardana B, Manatunge J (2020) Transmission of COVID-19 virus by droplets and aerosols: A critical review on the unresolved dichotomy. Environ Res 188: 109819. [Crossref]

50. Marthi B (1994) Resuscitation of microbial bioaerosols. In: Lighthart B., Mohr A.J. editors. Atmospheric Microbial Aerosols. Springer; Boston, MA. pp. 192-225.

51. Kumar P, Morawska L (2019) Could fighting airborne transmission be the next line of defence against COVID-19 spread? City Environ Interact 4: 100033.

52. Schuit M, Gardner S, Wood S, Bower K, Williams G, et al. (2020) The Influence of Simulated Sunlight on the Inactivation of Influenza Virus in Aerosols. J Infect Dis 221: 372-378. [Crossref]

53. Duguid JP (1945) The numbers and the sites of origin of the droplets expelled during expiratory activities. Edinb Med $J$ 52: 385-401. [Crossref]

54. Verreault D, Killeen SZ, Redmann RK, Roy CJ (2013) Susceptibility of monkeypox virus aerosol suspensions in a rotating chamber. J Virol Methods 187: 333-337. [Crossref]

55. Liu DL, Nazaroff WW (2001) Modeling pollutant penetration across building envelopes. Atmospheric Environ 35: 4451-4462.

56. Oberdörster G, Oberdörster E, Oberdörster J (2005) Nanotoxicology: an emerging discipline evolving from studies of ultrafine particles. Environ Health Perspect 113 823-839. [Crossref]

57. Nazaroff WW (2004) Indoor particle dynamics. Indoor Air 14: 175-183. [Crossref]

58. Qian J, Hospodsky D, Yamamoto N, Nazaroff WW, Peccia J (2012) Size-resolved emission rates of airborne bacteria and fungi in an occupied classroom. Indoor Air 22: 339-351. [Crossref]

59. Siegel JD, Rhinehart E, Jackson M, Chiarello L; Health Care Infection Control Practice Advisory Committee (2007) 2007 Guideline for Isolation Precautions: Preventing Transmission of Infectious Agents in Health Care Settings. Am J Infect Control 35: S65-S164. [Crossref]

60. Ching P, Harriman K, Li Y, et al. (2007) Infection prevention and control of epidemicand pandemic-prone acute respiratory diseases in health care: WHO interim guidelines. Document WHO/CDS/EPR/2007.6, Geneva, Switzerland, World Health Organization, pp. 90, 2007.

61. Fennelly KP (2020) Particle sizes of infectious aerosols: implications for infection control. Lancet Respir Med 8: 914-924. [Crossref]

62. Bai Y, Yao L, Wei T, Tian F, Jin DY, et al. (2020) Presumed Asymptomatic Carrier Transmission of COVID-19. JAMA 323: 1406-1407. [Crossref]

63. Zou L, Ruan F, Huang M, Liang L, Huang H, et al. (2020) SARS-CoV-2 Viral Load in Upper Respiratory Specimens of Infected Patients. N Engl J Med 382: 1177-1179. [Crossref]

64. Chen YC, Huang LM, Chan CC, Su CP, Chang SC, et al. (2004) SARS Research Group of National Taiwan University College of Medicine and National Taiwan University Hospital. SARS in hospital emergency room. Emerg Infect Dis 10: 782-788. [Crossref]

65. Otter JA, Donskey C, Yezli S, Douthwaite S, Goldenberg SD, et al. (2016) Transmission of SARS and MERS coronaviruses and influenza virus in healthcare settings: the possible role of dry surface contamination. J Hosp Infect 92: 235-250. [Crossref]

66. Chan KH, Peiris JS, Lam SY, Poon LL, Yuen KY, et al. (2011) The Effects of Temperature and Relative Humidity on the Viability of the SARS Coronavirus. $A d v$ Virol 2011: 734690. [Crossref]

67. Knibbs LD, Morawska L, Bell SC, Grzybowski P (2011) Room ventilation and the risk of airborne infection transmission in 3 health care settings within a large teaching hospital. Am J Infect Control 39: 866-872. [Crossref]

68. European Center for Disease Prevention and Control (2020) Heating, ventilation and air-conditioning systems in the context of COVID-19.

69. Lu J, Gu J, Li K, Xu C, Su W, et al. (2020) COVID-19 Outbreak Associated with Air Conditioning in Restaurant, Guangzhou, China, 2020. Emerg Infect Dis 26: 1628-1631. [Crossref] 
70. Rothe C, Schunk M, Sothmann P, Bretzel G, Froeschl G, et al. (2020) Transmission of 2019-nCoV Infection from an Asymptomatic Contact in Germany. N Engl J Med 382: 970-971. [Crossref]

71. Correia G, Rodrigues L, Gameiro da Silva M, Gonçalves T (2020) Airborne route and bad use of ventilation systems as non-negligible factors in SARS-CoV-2 transmission. Med Hypotheses 141: 109781. [Crossref]

72. Hayden CS, Johnston OE, Hughes RT, Jensen PA (1998) Air volume migration from negative pressure isolation rooms during entry/exit. Appl Occupational Environmental Hygiene 13: 518-527.

73. Edge BA, Paterson EG, Settles GS (2005) Computational study of the wake and contaminant transport of a walking human. J Fluids Engineering 127: 967-977.

74. Tang JW, Eames I, Li Y, Taha YA, Wilson P, et al. (2005) Door-opening motion can potentially lead to a transient breakdown in negative-pressure isolation conditions: the importance of vorticity and buoyancy airflows. J Hosp Infect 61: 283-286. [Crossref]

75. Tang JW, Li Y, Eames I, Chan PK, Ridgway GL (2006) Factors involved in the aerosol transmission of infection and control of ventilation in healthcare premises. $J$ Hosp Infect 64: 100-114. [Crossref]

76. Perry JL, Agui JH, Vijayakumar R (2016) Submicron and Nanoparticulate Matter Removal by HEPA-Rated Media Filters and Packed Beds of Granular Materials. NASA report NASA/TM 2016: 218224.

77. Tong ZD, Tang A, Li KF, Li P, Wang HL, et al. (2020) Potential Presymptomatic Transmission of SARS-CoV-2, Zhejiang Province, China, 2020. Emerg Infect Dis 26 : 1052-1054. [Crossref]

78. American Society of Heating, Refrigerating, and Air-Conditioning Engineers (2004) ANSI/ASHRAE Standard 55-2004: Thermal Environmental Conditions for Human Occupancy. Atlanta, Ga, USA, American Society of Heating, Refrigerating, and AirConditioning Engineers.

79. American Society of Heating, Refrigerating, and Air-Conditioning Engineers (2004) ANSI/ASHRAE/IESNA Standard 90.1-2004: Energy Standardh for Buildings Excep Low-Rise Residential Buildings. Atlanta, Ga, USA, American Society of Heating, Refrigerating, and Air-Conditioning Engineers.
80. American Society of Heating, Refrigerating and Air-Conditioning Engineers (2003) Report of Presidential Ad Hoc Committee for Building Health and Safety under Extraordinary Incidents on: Risk Management Guidance for Health, Safety, and Environmental Security under Extraordinary Incidents. Atlanta, Ga, USA, American Society of Heating, Refrigerating and Air-Conditioning Engineers.

81. Bearg, D. W. (2001) HVAC systems. J. D. Spengler, J. M. Samet, and J. F. McCarthy, Eds., In: Indoor Air Quality Handbook. McGraw-Hill, New York, NY, pp. 7.1-7.18.

82. National Academies of Sciences, Engineering, and Medicine; National Academy of Engineering; Division on Engineering and Physical Sciences; Health and Medicine Division; Division on Earth and Life Studies; Board on Infrastructure and the Constructed Environment; Board on Environmental Studies and Toxicology; Board on Life Sciences; Committee on Microbiomes of the Built Environment: From Research to Application. Microbiomes of the Built Environment: A Research Agenda for Indoor Microbiology, Human Health, and Buildings. Washington (DC): National Academies Press (US); 2017 Aug 16. 3, The Built Environment and Microbial Communities. Available at: https://www.ncbi.nlm.nih.gov/books/NBK458823/

83. John Hopkins Bloomberg School of Public Health (JHBSPH) (2008) Protecting Building Occupants from Exposure to Biological Threats. Center for Health Security. Available at: http://www.upmc biosecurity.org/website/resources/multimedia/2008protecting_building_occupants/building_vulnerability.html

84. EPA 2009 Swine H1N1 Influenza A: Transmission of Viruses in Indoor Air: HVAC System Protection Options," Federal Interagency Committee for Indoor Air Quality. Environmental Protection Agency.

85. Hitchcock PJ, Mair M, Inglesby TV, Gross J, Henderson DA, et al. (2006) Improving performance of HVAC systems to reduce exposure to aerosolized infectious agents in buildings; recommendations to reduce risks posed by biological attacks. Biosecur Bioterror 4: 41-54. [Crossref]

86. Persily AK, Chapman RE, Emmerich SJ, Dols WS, Davis H, et al. (2007) Building Retrofits to Protect Against Airborne Chemical and Biological Releases (NISTIR 7379). Washington, DC: National Institute of Standards and Technology.

87. Chan JF, Yuan S, Kok KH, To KK, Chu H, et al. (2020) A familial cluster of pneumonia associated with the 2019 novel coronavirus indicating person-to-person transmission: a study of a family cluster. Lancet 395: 514-523. [Crossref]

Copyright: $\odot 2021$ Ezeani MC. This is an open-access article distributed under the terms of the Creative Commons Attribution License, which permits unrestricted use, distribution, and reproduction in any medium, provided the original author and source are credited. 